\title{
"Relational Capital and financial performance: an empirical analysis on a sample of Italian firms"
}

\begin{tabular}{|c|c|}
\hline AUTHORS & $\begin{array}{l}\text { Gianpaolo lazzolino (D https://orcid.org/0000-0001-9756-1223 } \\
\text { Federica Chiappetta } \\
\text { Stefano Chiappetta }\end{array}$ \\
\hline ARTICLE INFO & $\begin{array}{l}\text { Gianpaolo lazzolino, Federica Chiappetta and Stefano Chiappetta (2018). } \\
\text { Relational Capital and financial performance: an empirical analysis on a sample } \\
\text { of Italian firms. Problems and Perspectives in Management, 16(1), 245-258. } \\
\text { doi:10.21511/ppm.16(1).2018.24 }\end{array}$ \\
\hline DOI & http://dx.doi.org/10.21511/ppm.16(1).2018.24 \\
\hline RELEASED ON & Wednesday, 14 March 2018 \\
\hline RECEIVED ON & Saturday, 25 November 2017 \\
\hline ACCEPTED ON & Thursday, 08 February 2018 \\
\hline LICENSE & $\begin{array}{l}(c) \text { EY } \\
\text { This work is licensed under a Creative Commons Attribution } 4.0 \text { International } \\
\text { License }\end{array}$ \\
\hline JOURNAL & "Problems and Perspectives in Management" \\
\hline ISSN PRINT & $1727-7051$ \\
\hline ISSN ONLINE & $1810-5467$ \\
\hline PUBLISHER & LLC "Consulting Publishing Company "Business Perspectives" \\
\hline FOUNDER & LLC "Consulting Publishing Company "Business Perspectives" \\
\hline
\end{tabular}

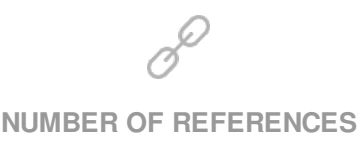

40

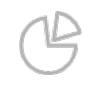

NUMBER OF FIGURES

3
NUMBER OF TABLES

12

(C) The author(s) 2023. This publication is an open access article. 


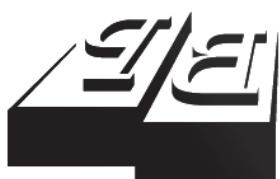

BUSINESS PERSPECTIVES

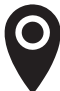

LLC "CPC "Business Perspectives" Hryhorii Skovoroda lane, 10, Sumy, 40022, Ukraine

www.businessperspectives.org

Received on: $25^{\text {th }}$ of November, 2017 Accepted on: $8^{\text {th }}$ of February, 2018

(c) Gianpaolo Iazzolino, Federica

Chiappetta, Stefano Chiappetta, 2018

Gianpaolo Iazzolino, Ph.D., Assistant Professor in Business Economics, Department of Mechanical, Energy and Management Engineering, University of Calabria, Italy.

Federica Chiappetta, M.Sc., scholarship holder in Business Economics, Department of Mechanical, Energy and Management Engineering, University of Calabria, Italy.

Stefano Chiappetta, M.Sc., Analyst of CRM Systems Everis Italia SpA, Italy.

\section{(ㄷ)(ㄱ)}

This is an Open Access article, distributed under the terms of the Creative Commons Attribution 4.0 International license, which permits unrestricted re-use, distribution, and reproduction in any medium, provided the original work is properly cited.

\section{RELATIONAL CAPITAL AND FINANCIAL PERFORMANCE: AN EMPIRICAL ANALYSIS ON A SAMPLE OF ITALIAN FIRMS}

\begin{abstract}
The aim of this paper is to study the relations existing between the relational capital, both internal and external, and the firm financial performance. The investigation has been carried out on quantitative and qualitative data extracted from a sample of 100 Italian large firms. The paper deeply analyzes the dimension of the internal relational capital, not so widely studied in the literature. Findings demonstrate the influence of the internal relational capital (IRC) and of the external relational capital (ERC) on performance. The research suggests that an effort has to be devoted not only to improving relations with external stakeholders, but also to developing intra-firm relations. The research contributes to studies in management and in particular in internal organization by demonstrating that designing and implementing systems for supporting internal relation can improve firm performance.
\end{abstract}

Keywords

JEL Classification intellectual capital, relational capital, financial performance, AIDA

\section{INTRODUCTION}

It is globally recognized that intellectual capital represents the key resource for economic improvement and growth and has an important role in the evaluation of firm performance (Alipour, 2012; Youndt et al., 2004; Stewart, 1997; Thurow, 1999; Petty \& Guthrie, 2000; Bontis, 2001; Zambon, 2013; Iazzolino \& Migliano, 2016).

The debate about intangible assets or for example the intellectual capital (IC) started with Edvinsson and Malone (1997) and Sveiby (1997) and has not been settled yet. Scholars and practitioners tend to agree on the idea that human capital (HC), structural capital (SC) and relational capital (RC) are the main components of the IC. The structure of the firm's IC is not the only open point of the debate. The relationship between IC and firm's performance is also a crucial point.

More and more scholars have shown an interest in this topic and have started to carry out research in order to define the contribution to financial performance of the intellectual capital and/or, more precisely, of its three components.

This paper considers, within the three components of the IC, only the relational capital and its impact on the financial performance of the firm. The dimension of relational capital can be considered in the two forms of external relational capital (ERC) and internal relational capital (IRC). In this paper, the relation between the relational capital, 
both internal and external, and financial performance is analyzed. The investigation has been carried out on quantitative and qualitative data, extracted from a sample of 100 Italian large firms.

The paper contributes to research from both theoretical and practical point of view. From theoretical point of view, it has been demonstrated that a good support to internal organizational relations can improve performance; from practical point of view, firms are suggested to pay attention to designing specific systems for supporting internal organizational relations, as they can positively impact on performance.

Section 1 describes the literature review. Section 2 describes the methodology, the sample and the indicators used in the research. Results and discussion are included in sections 3 and 4 . Next section describes limitations and future research. Last section concludes the paper.

\section{LITERATURE REVIEW}

Knowledge represents the key resource for generating a competitive advantage and for increasing firm value. Chen et al. (2005), Phusavat et al. (2011), Tan et al. (2007), Razafindrambinina and Anggreni (2011), Wang (2011), Alipour (2012), Maditinos et al. (2011), Joshi et al. (2013) have developed different frameworks aimed at analyzing this relation, by considering the components of the Value Added Intellectual Coefficient (VAIC) (Pulic, 2000). Other studies were carried out on firm performance and different ways for analyzing it (Iazzolino et al., 2013).

Scholars and practitioners have been debating about the meaning and the economic value of IC since Edvinsson and Malone (1997) and Sveiby (1997). They converge on the idea that the IC consists of three groups of intangible assets, respectively, related to:

- Human capital (HC): experience, knowledge, intellect, behavior, relationship, attitude and special skills of employees.

- Structural capital (SC): non-human storehouses of knowledge existing in organizations, technologies, organization, innovation practices generating value.

- Relational capital (RC): the value generated by inter-organizational relations or relations existing between the firm and for example suppliers, customers, shareholders and other institutions and individuals.

Some papers investigated the relation between intellectual capital (IC) and firm value also from the strategic point of view (Baiburina \& Golovko, 2008; Huang \& Wang, 2008). Demartini et al. (2015) investigated the relationships between IC, business performance and sustainability management to propose a model for measuring and managing intangible assets. A methodology for auditing strategic resources and dynamics of value creation is proposed by Battagello et al. (2016). Kianto et al. (2014) studied the impact of both static (IC assets) and dynamic Knowledge Management (KM) practices) aspects of organizational knowledge on the value creation process in organizations.

A methodology to assess the capacity of communities of innovation to improve the value creation process was proposed in Grimaldi et al. (2012). A tool based on system dynamics has been used by Zakeryet al. (2017) for monitoring and improving the alignment of firm's key resources with the market growth strategy.

According to Prahalad and Ramaswany (2000), relational capital is one of the most important dimensions of the IC. García-Merino et al. (2014), Vishnu and Gupta (2014), Mention and Bontis (2013), Cabrita and Bontis (2008), Wang et al. (2014) investigated this specific dimension of IC. There are not further empirical evidences analyzing only this component of the IC.

Furthermore, there are very few scientific evidences concerning the internal relational capital. The organizational relational model (Ferioli \& Migliarese, 1996) is one of the available models in the literature that can allow the intra-organizational relations to be studied in qualitative terms. The relation is intended as a social-economic entity between two actors. The organizational rela- 
tion is a link between individuals and/or organizations (or parts of organizations) aimed to a common task/objective. The organizational relation can be analyzed by considering the following four dimensions (Ferioli \& Migliarese, 1996):

- goals: represent the objectives in a relation;

- tools: support the relation by improving coordination, communication and information among its actors;

- organizational rules: represent the standards, tacit or explicit, that define the acceptable behavior for creating and managing the relation;

- cultural background: represents all the implicit key assumptions and the shared values between the actors of the relation.

On the basis on these attributes, it is possible to evaluate, in qualitative terms, the relationships within an organization. Further researches of the same authors have deepened the model, describing some applications (Laise et al., 2005; Migliarese \& Corvello, 2010).

\section{RESEARCH METHODOLOGY}

The aim of this paper is to identify the relation between the different components of the relational capital, both internal and external, and the financial performance of a sample of Italian firms. The time frame for the analysis is 8 years (from 2006 to 2013).
The 8 years time horizon is valid for the financial performance indicators and for 3 (out of 4) variables of the external relational capital. The other variables (purely qualitative) are calculated for the last year of the time frame (2013).

The framework of the research is briefly represented in Figure 1 below.

\subsection{Data sources and sample}

The sample used for the research is composed by 100 Italian firms. The selection was carried out on the AIDA database (Bureau Van Dijk) through the following research criteria:

- active legal status: only firms still in business;

- number of employees: 1,000 or more, at least in one year of the time horizon;

- sales revenue: $1,000,000,000 €$ or more, at least in one year of the time horizon.

The reason for choosing big-scale firms is mainly due to two factors: (i) big-scale firms invest in relational capital (and, more generally, in intellectual capital) to a greater extent than small firms; (ii) information is more readily available for larger companies, and this is particularly important when identifying elements regarding relational capital, that is, for its nature, hard to assess.

Through the illustrated criteria, a sample of 151 firms was selected. It was reduced to 100 because

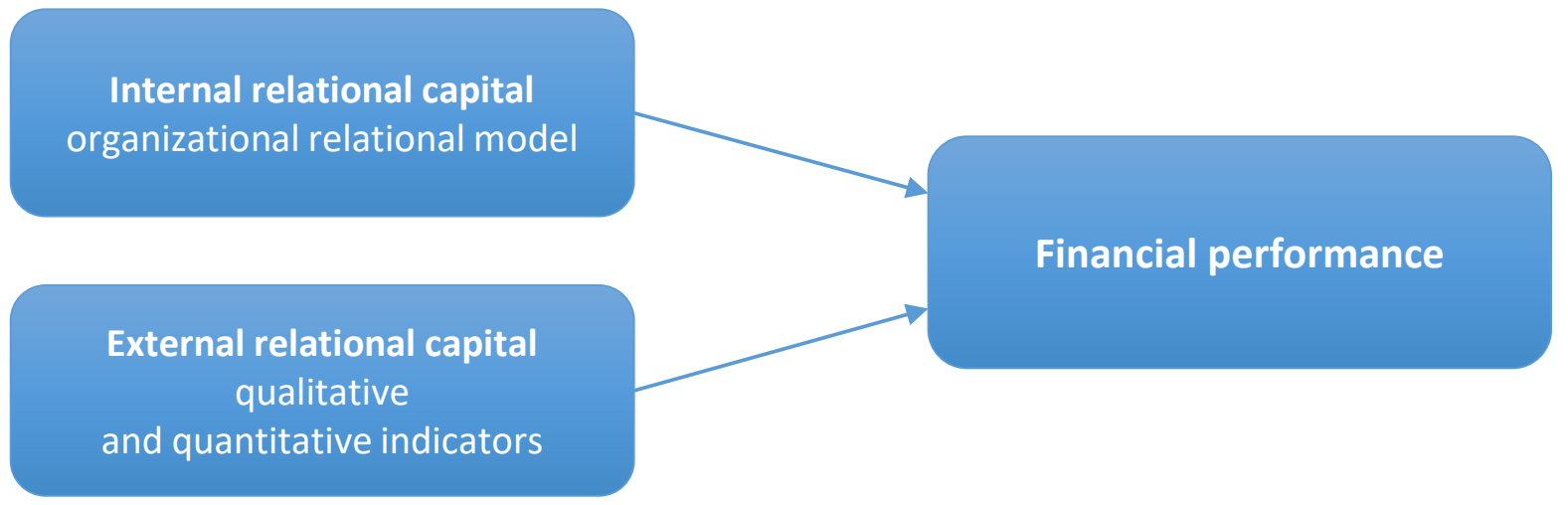

Figure 1. Research framework 
of lacking data. After that, a deep analysis on the firms' websites was carried out.

Then, the overall data sources were:

- The firms' annual reports (including social and sustainability reports).

- The firms' websites.

- The firms' financial data (collected from the AIDA database and/or from reports).

\subsection{Independent variables}

In order to express the value of the relational capital, both internal and external, 8 variables has been used, 4 for the internal relational capital and 4 for the external relational capital.

For evaluating the internal relational capital, the organizational relational capital (Ferioli \& Migliarese, 1996; Laise et al., 2005; Migliarese \& Corvello, 2010) has been used. The internal relational capital consists of qualitative variables only. Their value is calculated by using a scale of 1 to 5 with subjective criteria (Table 1).

Table 1. Scale used for qualitative assessment

\begin{tabular}{l|l}
\hline 1 & LOW \\
\hdashline 2 & MID-LOW \\
\hdashline 3 & MID \\
\hdashline 4 & MID-HIGH \\
\hdashline 5 & HIGH \\
\hline
\end{tabular}

\section{Variables are:}

Tools: they support the relation, providing tools to establish and maintain it, and they improve cooperation, communication and information between the subjects of the relation. This variable is divided into:

1. Formal/informal sharing tools: sharing and cohesion tools for employees, both formal (meeting, training courses) and informal (team building events, such as football match between colleagues).

2. Sharing software: information tools for communication, sharing information, working used by employees.
3. Training and development tools: tools and instruments for employees training and development.

Goals: they represent the objectives and their sharing in a relation. They can be divided into:

1. Reporting tools and transparency: reporting systems and degree of transparency of business information.

2. Systems for quality of work: e.g. non-discrimination, reconciliation of private, family and working life.

3. Remuneration and incentive systems.

4. Training and development systems: tools and means for training and development of employees.

Organizational rules: they represent the standards, tacit or explicit, that define the acceptable behaviors and the admissible methods for creating and managing relations. They can be divided into:

1. Reporting tools and transparency: reporting systems and degree of transparency of business information.

2. Ethical code.

3. Internal control, safety and health systems: internal control and risk management (supervisory organ, guarantees, management of relationships with suppliers and customers) and tools to ensure safety and health on the workplace.

4. Statute: policy instrument regulating the organization and the functioning of companies (rules and dispositions valid into the organization).

Cultural background: it represents all the implicit key assumptions and the shared values between the actors of the relation. It can be divided into:

1. Shared values on environment and social responsibility: shared assumptions in respect of environment and social responsibility (com- 
panies sensitize their employees to pursue objectives related to these aspects).

2. Model 231: adoption of an organizational, management and control model (commonly "Model 231") in accordance with Italian Legislative Decree 231 as of June 8, 2001, No 231 as anti-corruption legislation and, in general, crimes prevention from people working in the company. The concept is applicable also to the field of organizational relations inside the companies, because the model pursues principles of fairness and loyalty towards both external stakeholders and employees.

3. External reputation: external acknowledgement for corporate governance (in the respect of Civil Code or specific certifications).

The external relational capital is assessed through the following qualitative-quantitative indicators:

- total share holdings (in EUR 1000): this item includes participations in subsidiaries, affiliated undertakings and parent companies. This variable allows to evaluate the willingness of the firm to construct relationships with other organizations from financial point of view;

- sales revenues/number of employees (in EUR 1000): it expresses the performance of a single employee of the company;

- growth rate of revenues (as a percentage, calculated year by year): it expresses, as a percentage, the growth/decrease of revenues between two accounting years;

- relations with stakeholders: it assesses the degree of involvement of the company in the relationships with its stakeholders. It can be divided into the following sub-categories:

- relationships for research, development and innovation of product/service: level of commitment of the company to invest for offering more competitive products/services to customers;

- relationships for environmental sustainability (environment certifications): level of interest of the firm on environmental issues and its effort in the reduction of $\mathrm{CO}_{2}$, development of "green" products, development of employees' awareness on environmental matters;

- relationships with other stakeholders (humanitarian organizations, sponsorship, communities, associations): commitment of the firm in social issues (fundraiser, foundations), in sponsorships (culture, arts, music, sports), in cooperation with communities and/or associations.

The value of first three abovementioned variables can be calculated using the AIDA database, while the value of the last one is obtained by calculating the average of values assigned to its sub-variables, through a subjective and qualitative evaluation, according to the scale in Figure 2. For both types of relational capital, qualitative variables are assessed with a value referred to the last year (2013).

Table 2 summarizes the independent variables.

Table 2. Variables of the internal and external relational capital

\begin{tabular}{|c|c|}
\hline $\begin{array}{l}\text { INTERNAL RELATIONAL } \\
\text { CAPITAL }\end{array}$ & $\begin{array}{l}\text { EXTERNAL RELATIONAL } \\
\text { CAPITAL }\end{array}$ \\
\hline $\begin{array}{l}\text { Tools } \\
\text { 1. Sharing software. } \\
\text { 2. Formal/informal sharing } \\
\text { tools. } \\
\text { 3. Training and development } \\
\text { tools. }\end{array}$ & Total shareholdinngs \\
\hline $\begin{array}{l}\text { Goals } \\
\text { 1. Reporting tools } \\
\text { and transparency. } \\
\text { 2. Systems for quality } \\
\text { of work. } \\
\text { 3. Remuneration and } \\
\text { incentive systems. } \\
\text { 4. Training and development } \\
\text { tools. }\end{array}$ & $\begin{array}{l}\text { Sales revenues/number } \\
\text { of employees }\end{array}$ \\
\hline $\begin{array}{l}\text { Organizational rules } \\
\text { 1. Reporting tools and } \\
\text { transparency. } \\
\text { 2. Ethical code. } \\
\text { 3. Internal control and safety } \\
\text { and health systems. } \\
\text { 4. Statute. }\end{array}$ & Growth rate of revenues \\
\hline $\begin{array}{l}\text { Cultural background } \\
\text { 1. Shared values on } \\
\text { environment and social } \\
\text { responsibility. } \\
\text { 2. Model } 231 \text {. } \\
\text { 3. External reputation. }\end{array}$ & $\begin{array}{l}\text { Relations with stakeholders } \\
\text { 1. Relationships for } \\
\text { environmental } \\
\text { sustainability. } \\
\text { 2. Relationships for research, } \\
\text { development and } \\
\text { innovation of product/ } \\
\text { service. } \\
\text { 3. Relationships with other } \\
\text { stakeholders. }\end{array}$ \\
\hline
\end{tabular}




\subsection{Dependent variables}

The financial performance variables considered in this paper are the following:

1. EBITDA (in EUR 1000): Earnings Before Interest, Taxes, Depreciation and Amortization.

2. EBITDA/Sales (in percentage): it is a very important profitability index at an operating level of the firm.

3. EBITDA/Total assets (in percentage): it is useful to assess the profitability of invested capital.

In the following table, the considered variables are summarized.

Table 3. The financial performance indicators considered

\begin{tabular}{|c|c|c|}
\hline \multicolumn{3}{|c|}{ FINANCIAL PERFORMANCE } \\
\hline EBITDA & EBITDA/Sales & $\begin{array}{l}\text { EBITDA/Total } \\
\text { assets }\end{array}$ \\
\hline
\end{tabular}

\subsection{Research and analysis tools}

The following statistical tools were used for research:

1. Internal consistency analysis of the independent variables (Cronbach's Alpha) and analysis of the degree of multicollinearity between the independent variables (Tolerance index and VIF - Variance Inflaction Factor).

2. Analysis of potential significant relations between dependent and independent variables through correlation analysis and multiple linear regression.

In order to take back all variables in a common and single scale, the normalization min-max has been carried out for non-qualitative data, reducing them to the range [1,5], the same used for qualitative variables. Moreover, the average value on the time frame 2006-2013 has been considered for non-qualitative variables.

\section{RESULTS}

In this section, the abovementioned analysis is described. All the calculations have been carried out through IBM SPSS Statistics 22. Only the most significant results are presented. For further details please contact the authors of the paper.

\subsection{Internal consistency analysis of the internal relational capital variables}

The internal consistency analysis of IRC factors has been carried out through Cronbach's Alpha in order to verify if each sub-variable gives a real contribution to the value of the variable it belongs to. It is possible to say that all IRC variables have a sufficient internal consistency for validating reliability.

\subsection{Correlation analysis}

The correlation between the variables has been analyzed through the Pearson coefficient. The only correlations with a good significance, but still with a low Pearson coefficient, exist between the following variables:

- tools and EBITDA, with a correlation coefficient $\rho=0.219$;

- tools and EBITDA/Sales revenues, with a correlation coefficient $\rho=0.220$;

- goals and EBITDA/Sales revenues, with a correlation coefficient $\rho=0.239$;

- relations with stakeholders and EBITDA/ Sales revenues, with a correlation coefficient $\rho=0.208$.

The remaining correlation coefficients between dependent and independent variables show lower values.

\subsection{Multicollinearity analysis}

It has been necessary to carry out a multicollinearity diagnosis on independent variables of some regression models, as we see later on. The results follow. 
Table 4. Collinearity diagnosis on IRC variables

\begin{tabular}{l|c:c}
\hline $\begin{array}{c}\text { Internal Relational } \\
\text { Capital variables }\end{array}$ & \multicolumn{2}{c}{ Collinearity statistics } \\
\cline { 2 - 3 } & Tolerance & VIF \\
\hline Tools & 0.455 & 2.199 \\
\hline Goals & 0.293 & 3.416 \\
\hline Organizational rules & 0.467 & 2.141 \\
\hdashline Cultural background & 0.606 & 1.651 \\
\hline
\end{tabular}

Tolerance indices are not high, but at the same time, are not so low to prejudice significant multicollinearity presence. Moreover, VIF values are below the acceptable threshold of collinearity.

In summary, it can be said that there is a certain degree of collinearity between IRC variables, but it is pretty low. Therefore, there is a low risk that these variables affect validity of regression models.

It does not exist collinearity within E.R.C. variables, thus regression models for them are valid.

Table 5. Collinearity diagnosis on ERC variables

\begin{tabular}{|c|c|c|}
\hline \multirow{2}{*}{$\begin{array}{l}\text { External Relational } \\
\text { Capital variables }\end{array}$} & \multicolumn{2}{|c|}{ Collinearity statistics } \\
\hline & Tolerance & VIF \\
\hline Total holdings & 0.967 & 1.034 \\
\hline $\begin{array}{l}\text { Sales revenues/ } \\
\mathrm{N} \text { of employees }\end{array}$ & 0.980 & 1.021 \\
\hline Growth rate of revenues & 0.936 & 1.068 \\
\hline $\begin{array}{l}\text { Relations with } \\
\text { stakeholders }\end{array}$ & 0.956 & 1.046 \\
\hline
\end{tabular}

\subsection{Regression analysis}

In order to build up the regression models, the contribution given from IRC and ERC variables to financial performance has been checked separately. Each of the following models can be divided in three sub-models, depending on the considered dependent variable:

Model 1. Models 1.1, 1.2, 1.3 (relation of IRC to Financial performance)

$P_{i}=\beta_{0}+\beta_{1} \cdot$ Tools $+\beta_{2} \cdot$ Goals +

$+\beta_{3} \cdot$ Organisational Rules +

$+\beta_{4} \cdot$ Cultural Background +

$+\varepsilon, i=1,2,3$.
Model 2. Models 2.1, 2.2, 2.3 (relation of ERC to Financial performance)

$$
\begin{aligned}
& P_{i}=\beta_{0}+\beta_{1} \cdot \text { Total Holdings }+ \\
& +\beta_{2} \cdot \frac{\text { Sales Revenues }}{\text { Number of employees }}+ \\
& +\beta_{3} \cdot \text { Growth rate of revenues }+ \\
& +\beta_{4} \cdot \text { Relations with stakeholders }+ \\
& +\varepsilon, i=1,2,3 .
\end{aligned}
$$

The variable $P_{i}, i=1,2,3$, refers to financial performance variables:

- $\quad P_{1}=$ EBITDA (model 1.1 and model 2.1);

- $P_{2}=$ EBITDA/Sales revenues $($ model 1.2 and model 2.2);

- $\quad P_{3}=E B I T D A /$ Total assets (model 1.3 and model 2.3).

In the following, the most significant results of the regression analysis are shown. For further details please contact the authors of the paper. Particularly, for each model, there are coefficients of determination, results of F-test and estimated partial coefficients of regression, as outputs.

Table 6. Overview of model 1.2

\begin{tabular}{|c|c|c|c|c|c|c|}
\hline \multicolumn{7}{|c|}{ ANOVAa } \\
\hline & Model & $\underset{\text { squares }}{\text { Sum of }}$ & df & $\begin{array}{l}\text { Mean } \\
\text { square }\end{array}$ & $\mathbf{F}$ & Sign \\
\hline \multirow{3}{*}{1.2} & Regression & 2.742 & 4 & 0.685 & 2.868 & $0.027 b$ \\
\hline & Residue & 22.704 & 95 & 0.239 & - & - \\
\hline & Total & 25.446 & 99 & - & - & - \\
\hline
\end{tabular}

\begin{tabular}{c|c|c|c|c}
\hline \multicolumn{5}{c}{ Model overview } \\
\hline Model & $\mathbf{R}$ & $\mathbf{R 2}$ & $\begin{array}{c}\text { Adjusted } \\
\mathbf{R 2}\end{array}$ & $\begin{array}{c}\text { Standard } \\
\text { error }\end{array}$ \\
\hline 1.2 & $0.328 \mathrm{a}$ & 0.108 & 0.070 & 0.48887 \\
\hline
\end{tabular}

Note: a. Predictors: (constant), Cultural background, Tools, Organizational rules, Goals.

Table 7. ANOVA of model 1.2

Note: a. Dependent variable: EBITDA/Sales. b. Predictors: (constant), Cultural background, Tools, Organizational rules, Goals. 
Table 8. T-test and estimation of regression coefficients for model 1.2

\begin{tabular}{|c|c|c|c|c|c|c|c|c|}
\hline \multicolumn{9}{|c|}{ Coefficients } \\
\hline & \multirow{2}{*}{ Model T } & \multicolumn{2}{|c|}{$\begin{array}{c}\text { Non-standardized } \\
\text { coefficients }\end{array}$} & \multirow[t]{2}{*}{$\begin{array}{l}\text { Standardized } \\
\text { coefficients }\end{array}$} & \multirow{2}{*}{$\mathbf{T}$} & \multirow{2}{*}{$\begin{array}{c}\text { Sign } \\
\text { Tolerance }\end{array}$} & \multicolumn{2}{|c|}{ Collinearity statistics } \\
\hline & & Std. Error & $\beta$ & & & & VIF & \\
\hline \multirow{5}{*}{1.2} & (Constant) & 2.426 & 0.335 & - & 7.236 & 0.000 & - & - \\
\hline & Tools & 0.035 & 0.109 & 0.046 & 0.321 & 0.749 & 0.455 & 2.199 \\
\hline & Goals & 0.321 & 0.153 & 0.376 & 2.102 & 0.038 & 0.293 & 3.416 \\
\hline & Organizational rules & -0.227 & 0.102 & -0.314 & -2.215 & 0.029 & 0.467 & 2.141 \\
\hline & Cultural background & 0.051 & 0.083 & 0.076 & 0.609 & 0.544 & 0.606 & 1.651 \\
\hline
\end{tabular}

Note: a. Dependent variable: EBITDA/Sales.

Model 1.2 has a coefficient $R^{2}=0.328$, better than model 1.1. Moreover, F-test states a significance of 0.027 , that confirms the presence of at least one independent variable significant for the model. Hypothesis confirmed by T-test that identifies two significant independent variables:

- Goals, with a significance of 0.038 (so less than $0,05)$ and a regression coefficient $\beta=0.376$, that confirms the positive correlation between this variable and the dependent variable EBITDA/Sales, previously emerged;

- Organizational rules, with a significance of 0.029 (so less than 0.05 ) and a regression coefficient $\beta=-0.314$. This variable has a negative impact on the dependent variable of model 1.2.

Model 1.2 demonstrates that the dependent variable is affected from two of the IRC variables.

\subsection{Regression analysis on internal relational capital variables}

In order to measure the real link existing within the variables of IRC, an "internal" regression analysis has been carried out. Each variable is chosen as dependent variable of the remaining ones. If a variable defined irrelevant in the previous section influences another variable that instead is significant, it can be assumed that an indirect link between the first and the financial performance exists.
The regression models are the following:

Model A:

Tools $=\beta_{0}+\beta_{1} \cdot$ Goals +

$+\beta_{2} \cdot$ Organisational Rules +

$+\beta_{3} \cdot$ Cultural Background $+\varepsilon$.

Model B:

Goals $=\beta_{0}+\beta_{1} \cdot$ Tools +

$+\beta_{2} \cdot$ Organisational Rules +

$+\beta_{3} \cdot$ Cultural Background $+\varepsilon$.

Model C:

Organisational Rules $=\beta_{0}+\beta_{1} \cdot$ Tools +

$\beta_{2} \cdot$ Goals $+\beta_{3} \cdot$ Cultural Background $+\varepsilon$.

Model D:

Cultural Background $=\beta_{0}+\beta_{1} \cdot$ Tools +

$+\beta_{2} \cdot$ Goals $+\beta_{3} \cdot$ Organisational Rules $+\varepsilon$.

Results from the regression analysis are shown in the following tables.

Table 9. Overview of model A

\begin{tabular}{|c|c|c|c|c|}
\hline \multicolumn{5}{|c|}{ Model overview } \\
\hline Model & $\mathbf{R}$ & R2 & $\begin{array}{c}\text { Adjusted } \\
\text { R2 }\end{array}$ & $\begin{array}{c}\text { Standard } \\
\text { error }\end{array}$ \\
\hline A & $0.738 a$ & 0.545 & 0.531 & 0.45976 \\
\hline
\end{tabular}

Note: a. Predictors: (constant), Cultural background, Tools, Organizational rules, Goals. 
Table 10. ANOVA of model A

\begin{tabular}{|c|c|c|c|c|c|c|}
\hline \multicolumn{7}{|c|}{ ANOVAa } \\
\hline & Model & $\begin{array}{l}\text { Sum of } \\
\text { squares }\end{array}$ & df & $\begin{array}{l}\text { Mean } \\
\text { square }\end{array}$ & $F$ & Sign \\
\hline \multirow{3}{*}{ A } & Regression & 24.325 & 3 & 8.108 & 38.358 & $0.000 \mathrm{~b}$ \\
\hline & Residue & 20.293 & 96 & 0.211 & - & - \\
\hline & Total & 44.618 & 99 & - & - & - \\
\hline
\end{tabular}

Notes: a. Dependent variable: Tools. b. Predictors: (constant), Cultural background, Tools, Organizational rules, Goals.

Model A has a coefficient $R^{2}=0.738$. F-test states a significance of 0.000 , thus it exists at least an independent variable that significantly affects the dependent variable. T-test confirms that variable Goals, with a significance of 0.000 and a regression coefficient $\beta=0.795$, is the only significant variable of the model.

As regards model A, thus, the variable Goals has a significant impact on variable Tools.

\section{DISCUSSION}

Findings from correlation analysis demonstrate that:

- internal relational capital is linked to financial performance with particular reference to variables Tools and Goals;

- external relational capital is linked to financial performance with particular reference to variables Sales Revenues/Number of employees and Relations with stakeholders.

However, the correlations observed between dependent and independent variables are moderate.
This indicates that IRC and ERC do not play a relevant role in the determination of firm's financial performance. Thesis confirmed by the results of the regression analysis between IRC and ERC variables and financial performance that reveals that:

in all models, the determination coefficient and F-test and T-test have never reached particularly significant value; this confirms that it does not exist particularly relevant relations between IRC and ERC and the financial performance;

- two variables, for each of the relational capital, affect, although in a moderate way, some dependent variables, while the remaining independent variables result almost irrelevant. Particular attention need to be paid to the variable Sales Revenues/Number of employees, that influences the value of two dependent variables (EBITDA and EBITDA/Sales). It is clear indeed that a higher economic productivity per single employee implies a better profitability for the company. As regards the other variables:

- Goals positively impacts on EBITDA/Sales. It is reasonable that an efficient management and incentive system gives a contribution to improve profitability at an operating level;

- Organizational rules, not significant for correlation analysis, impacts negatively on EBITDA/Sales. In this case, results of the multiple regression analysis are considered more reliable. It can be said that, from an economic point of view, a management system for internal relations affects more in terms of increasing costs than in benefits;

Table 11. T-test and estimation of regression coefficients for model A

\begin{tabular}{|c|c|c|c|c|c|c|c|c|}
\hline \multicolumn{9}{|c|}{ Coefficients } \\
\hline & \multirow{2}{*}{ Model T } & \multicolumn{2}{|c|}{$\begin{array}{c}\text { Non-standardized } \\
\text { coefficients }\end{array}$} & \multirow[t]{2}{*}{$\begin{array}{c}\text { Standardized } \\
\text { coefficients }\end{array}$} & \multirow{2}{*}{$\mathbf{T}$} & \multirow{2}{*}{$\begin{array}{c}\text { Sign } \\
\text { Tolerance }\end{array}$} & \multicolumn{2}{|c|}{ Collinearity statistics } \\
\hline & & Std. Error & $\boldsymbol{\beta}$ & & & & VIF & \\
\hline \multirow{4}{*}{ A } & (Constant) & 0.503 & 0.311 & - & 1.616 & 0.109 & - & - \\
\hline & Goals & 0.897 & 0.111 & 0.795 & 8.111 & 0.000 & 0.493 & 2.027 \\
\hline & Organizational rules & -0.152 & 0.095 & -0.159 & -1.602 & 0.112 & 0.480 & 2.085 \\
\hline & Cultural background & 0.068 & 0.078 & 0.077 & 0.872 & 0.386 & 0.610 & 1.638 \\
\hline
\end{tabular}

Note: a. Dependent variable: Tools. 
Table 12. Overall regression analysis results

\begin{tabular}{|c|c|c|c|}
\hline Type of relational capital & \multicolumn{2}{|c|}{ Independent variables } & $\begin{array}{l}\text { Influenced variables } \\
\text { of financial performance }\end{array}$ \\
\hline \multirow{4}{*}{$\begin{array}{l}\text { IRC } \\
\text { Internal relational capital }\end{array}$} & Tools & $\rightarrow$ & - \\
\hline & Goals & $\rightarrow$ & EBITDA/Sales \\
\hline & Organizational rules & $\rightarrow$ & EBITDA/Sales \\
\hline & Cultural background & $\rightarrow$ & - \\
\hline \multirow{4}{*}{$\begin{array}{l}\text { ERC } \\
\text { External relational capital }\end{array}$} & Total holdings & $\rightarrow$ & - \\
\hline & Sales/Number of employees & $\rightarrow$ & $\begin{array}{l}\text { EBITDA } \\
\text { EBITDA/Sales }\end{array}$ \\
\hline & Growht rate of revenues & $\rightarrow$ & - \\
\hline & Relations with stakeholders & $\rightarrow$ & EBITDA/Sales \\
\hline
\end{tabular}

- Relations with stakeholders positively impacts on EBITDA/Sales. A company that takes care of stakeholders can get better operating results than others;

- EBITDA/Total assets results to be the only dependent variable that does not have relations with any independent variables, while EBITDA/Sales is the most influenced;

- Tools, resulting relevant for the correlation analysis, does not have a significant influence on firm's performance variables in the multiple regression analysis. Therefore, correlations previously evidenced between Tools and financial performance are random and not characterized by a relation of dependence. Also in this case, as for Organizational rules, regression analysis results are preferred because more reliable. As a consequence, it can be deducted that all financial performance do not have link of dependence with Tools.

In Table 11, the results of regression analysis between IRC and ERC variables and financial performance are briefly represented.
A regression analysis within IRC variables has been carried out because of a certain degree of multicollinearity between them. This analysis allowed to clarify some aspects. First of all, each model has a good coefficient of determination and this confirms the presence of multicollinearity between the IRC variables, even if it is low. The IRC variables are linked among them as in Figure 2. Then the two variables Tools and Cultural Background have at least indirect influence on financial performance, because these variables, which in the first regression analysis have not directly influenced the dependent variables, have a direct and significant connection with the variables Goals and Organisational Rules, which are significant for model 1.2.

Each of those relationships can be explained as follows:

- Tools and Goals: using effective tools for supporting internal relationships can allow better results in sharing and achieving goals to be reached, and vice versa;

Goals and Organizational Rules: a higher level of goal sharing allows a system of tacit or explicit rules accepted from everyone to be easier defined, and vice versa;

Figure 2. Results of regression within IRC variables 


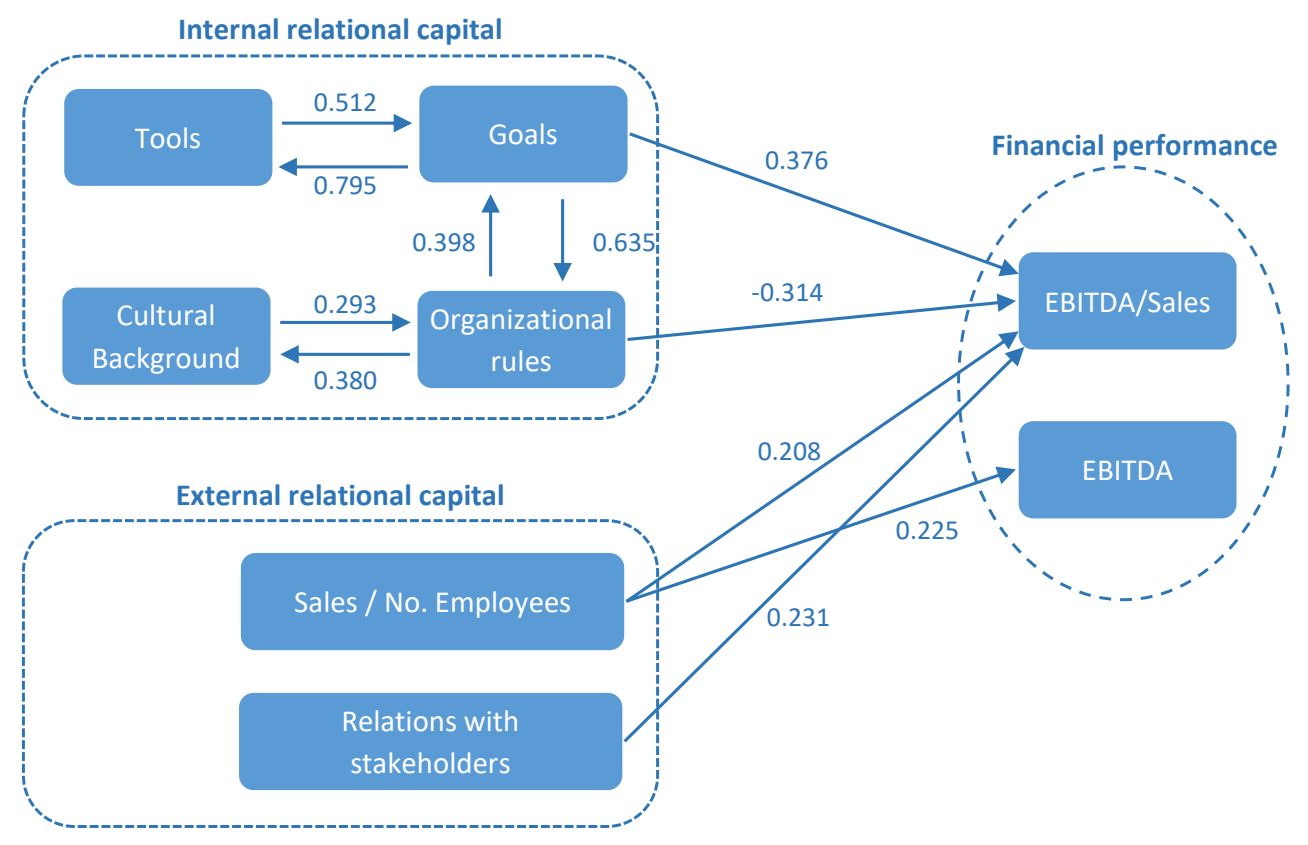

Figure 3. Framework of relations with $\beta$ coefficients

- Organizational Rules and Cultural Background: it is reasonable that a well defined set of rules makes sharing common values between the actors of a relation easier, and vice versa.

Figure 3 shows the complete framework with all the significant relations and their regression coefficients $\beta$.

Results of the analysis on external relational capital are in line with studies carried out by Cabrita and Bontis (2008), Wang et al. (2014) and Tseng and James Goo (2005), in which this dimension of intellectual capital has a positive relation with firm performance. Also researches of GarcíaMerino et al. (2014), Vishnu and Gupta (2014), Mention and Bontis (2013) founded a similar relation, with the difference that, in this paper, a good significance has been found, while in the abovementioned studies the contribution is not statistically significant. A common element for many studies of the literature is that a significant relation exists for a subset of the ERC variables only. In the studies by Wang (2008) and Yu and Zhang (2008), the relations between the relational capital and the market value are only partially verified. Results of these studies suggest that companies should develop and maintain external relations and, particularly, with customers, as the main source of success for the firm.
As regards the internal relational capital, Migliarese and Corvello (2010) claim that an organizational relation is coherent only if there is coherence between Tools, Goals, Organizational rules and Cultural Background. This statement is aligned with results achieved in the regression analysis on IRC variables, in which it has been found that these variables have an impact on each other, directly or indirectly. Instead, as stated by Laise et al. (2005), the creation of new knowledge does not arise from information already available in a database, but from existing organizational relations between different actors of the organization. ICT tools do not play active role in the creation of new knowledge, but they support individuals belonging to the organization in pursuing their objective. Consequently, as intellectual capital is based on knowledge, it is clear that IRC plays an important role in the value creation for the company. The presence of intense organizational relations between the actors of an organization is a necessary condition for the knowledge organization to be defined.

A more collaborative environment could improve business climate and employees' motivation (Calabrese et al., 2013). Also Drucker (1999) supports the importance of IRC by describing the future organizations as composed by professionals with high autonomy who promote collaboration relationships aimed at achieving the assigned objectives. 


\section{LIMITATIONS AND FURTHER RESEARCHES}

One of the limits of this research is the qualitative nature of some variables. They have been subjectively assessed.

Another limit is related to unavailability of information about indicators that could express in a better way the external relational capital. The variables used in this study interpret only partially that dimension of the intellectual capital.

A further limitation can be considered the choice of the linear regression analysis: there could exist relations also of non-linear type between the variables that in this paper have been recognized as not significantly related to each other.

For further researches, the internal relational capital could be evaluated through questionnaires and interviews. Regarding the external relational capital, it could be useful to use other kinds of indicators, as well as those already proposed in this study, of qualitative nature, obtainable from other Databases (DBs) or from accounting tools available on companies' websites.

Finally, the sample of firms could be extended and eventually also classified on a sector basis.

\section{CONCLUSION}

This work aims to study the relations existing between (i) internal and (ii) external relational capital to financial performance of a sample of big-scale Italian companies.

Literature concerning the intellectual capital is surely wide. Many scholars have carried out researches on the impact of intellectual capital on financial performance and the market value of the firm by using different statistical methodologies, often achieving contrasting results.

This paper is based on the assumption that, in addition to capital characterized by relations existing with the external environment, also internal relations have a significant importance for the performance of the firm. In this paper, the internal relational capital and its contribution to firm performance have been deeply analyzed.

Results of regression and correlation analysis show that a relation between the relational capital and financial performance exists. The study demonstrated the influence of the IRC and ERC on value creation process. It suggests focusing not only on improving relations with external stakeholders, but also on paying particular attention on intra-firm relations.

The paper contributes to research from both theoretical and practical point of view. From theoretical point of view, it has been demonstrated that good support for internal organizational relations can improve performance; from practical point of view, firms are suggested to pay attention in designing specific systems for supporting internal organizational relations, as they can positively impact on performance.

In particular, the attention of firms should be paid to the variables that impact more directly on financial performance, as already discussed in section 5 .

\section{REFERENCES}

1. Alipour, M. (2012). The effect of intellectual capital on firm performance: an investigation of Iran insurance companies. Measuring Business Excellence, 16(1), 53-66.
2. Baiburina, E. R., \& Golovko, T. V. (2008). Empirical investigation of intellectual enterprise value and its factors for big Russian companies. Corporate Finance, 2(6), 5-23.
3. Battagello, F. M., Cricelli, L., \& Grimaldi, M. (2016). Benchmarking strategic resources and business performance via an open framework. International Journal of Productivity and Per- 
formance Management, 65(3), 324-350.

4. Bontis, N. (2001). Assessing knowledge assets: a review of the models used to measure intellectual capital. International Journal of Technology Management, 3(1), 41-60.

5. Cabrita, M., \& Bontis, N. (2008). Intellectual capital and business performance in the Portuguese banking industry. International Journal of Technology Management, 43(1-3), 212-237.

6. Calabrese, A., Costa, R., Menichini, T., Rosati, F., \& Sanfelice, G. (2013). Turning corporate social responsibility (CSR)-driven opportunities in competitive advantages: A twodimensional model. Knowledge and Process Management, 20(1), 50-58.

7. Chen, M. C., Cheng, S. J., Hwang, Y. (2005). An empirical investigation of the relationship between intellectual capital and firms' market value and financial performance. Journal of Intellectual Capital, 6(2), 159-176. Retrieved from http://citeseerx.ist.psu.edu/ viewdoc/download?doi=10.1.1.46 7.4731\&rep=rep $1 \&$ type $=$ pdf

8. Demartini, P., Paoloni, M., \& Paoloni, P. (2015). Sustainability and intangibles: evidence of integrated thinking. Journal of International Business and Economics, 15(2), 107-122.

9. Drucker, P. F. (1999). Knowledge worker productivity: the biggest challenge. California Management Review, 41(2), 79-92. Retrieved from http://forschungsnetzwerk.at/downloadpub/ knowledge_workers_the_biggest_challenge.pdf

10. Edvinsson, L., \& Malone, M. (1997). Intellectual Capital: Realizing Your Company's True Value By Finding Its Hidden Brainpower. Harper Collins, New York, NY.

11. Ferioli, C., \& Migliarese, P. (1996). Supporting organisational relations through information technology in innovative organisational forms. European Journal of Information Systems, 5(3), 196-207.

12. García-Merino, J. D., GarcíaZambrano, L., \& RodriguezCastellanos, A. (2014). Impact of relational capital on business value. Journal of Information and Knowledge Management, 13(1). Retrieved from http://www.worldscientific.com/doi/abs/10.1142/ S0219649214500026

13. Grimaldi, M., Cricelli, L., \& Rogo, F. (2012). A methodology to assess value creation in communities of innovation. Journal of Intellectual Capital, 13(3), 305-330.

14. Huang, C., \& Wang, M. (2008). The effects of economic value added and intellectual. Capital on the market value of firms: an empirical study. International Journal of Management, 25(4), 722-731.

15. Iazzolino, G., \& Migliano, G. (2016). Positioning firms in a new business performance space: an empirical study design on Euronext listed companies. Investment Management and Financial Innovations, 13(4), 106119. http://dx.doi.org/10.21511/ imfi.13(4).2016.09

16. Iazzolino, G., Bruni, M. E., \& Beraldi, P. (2013). Using DEA and financial ratings for credit risk evaluation: an empirical analysis. Applied Economics Letters, 20(14), 1310-1317.

17. Joshi, M., Cahill, D., \& Sidhu, J. (2013). Intellectual capital and financial performance: an evaluation of the Australian financial sector. Journal of Intellectual Capital, 14(2), 264-285.

18. Kianto, A., Ritala, P., Spender, J.-C., \& Vanhala, M. (2014). The interaction of intellectual capital assets and knowledge management practices in organizational value creation. Journal of Intellectual Capital, 15(3), 362-375.

19. Laise, D., Migliarese, P., \& Verteramo, S. (2005). Knowledge Organization design: a diagnostic tool. Human systems management, 24(2), 121-131.

20. Maditinos, D., Chatzoudes, D., Tsairidis, C., \& Theriou, G. (2011). The impact of intellectual capital on firms' market value and financial performance. Journal of Intellectual Capital, 12(1), 132-151.

21. Mention, A-L., \& Bontis, N. (2013). Intellectual capital and performance within the banking sector of Luxembourg and Belgium. Journal of Intellectual Capital, 14(2), 286-309.

22. Migliarese, P., \& Corvello, V. (2010). Organisational relations in organisational design and engineering. Int. J. Organisational Design and Engineering, 1(1/2), 55-68.

23. Petty, R., \& Guthrie, J. (2000). Intellectual capital literature review: Measurement, reporting and management. Journal of Intellectual Capital, 1(2), 155-176.

24. Phusavat, K., Comepa, N., SitkoLutek, A., \& Ooi, K-B. (2011). Interrelationships between intellectual capital and performance empirical examination. Industrial Management \& Data Systems, 111(6), 810-829.

25. Prahalad, C. K., \& Ramaswamy, V. (2000). Co-opting Customer Competence. Harward Business Review, 78(1), 79-87.

26. Pulic, A. (2000). VAIC - an accounting tool for IC management. International Journal of Technology Management, 20(5-8), 702-714.

27. Razafindrambinina, D., \& Anggreni, T. (2011). Intellectual capital and corporate financial performance of selected listed companies in Indonesia. Malaysian Journal of Economic Studies, 48(1), 61-77.

28. Stewart, T. A. (1997). Intellectual Capital: The New Wealth of Organizations. New York: Bantam Dobleday Dell Publishing group, Inc.

29. Sveiby, K. E. (1997). The New Organizational Wealth: Managing \& Measuring Knowledge-Based Assets. Berrett-Koehler, San Francisco, CA.

30. Tan, H. P., Plowman, D., \& Hancock, P. (2007). Intellectual capital and financial returns of companies. Journal of Intellectual Capital, 8(1), 76-95. 
31. Thurow, L. C. (1999). Building Wealth: The New Rules for Individuals, Companies, and Nation in a Knowledge-Based Economic (1st ed.). HarperCollins, New York, NY.

32. Tseng, C-Y., \& James Goo, Y-J. (2005). Intellectual capital and corporate value in an emerging economy: empirical study of Taiwanese manufacturers. R\&D Management, 35(2), 187-201.

33. Vishnu, S., \& Gupta, V. K. (2014). Intellectual capital and performance of pharmaceutical firms in India. Journal of Intellectual Capital, 15(1), 83-99.
34. Wang, J-C. (2008). Investigating market value and intellectual capital for S\&P 500. Journal of Intellectual Capital, 9(4), 546-563.

35. Wang, M. (2011). Measuring intellectual capital and its effect on financial performance: evidence from the capital market in Taiwan. Frontiers of Business Research in China, 5(2), 243-265.

36. Wang, Z., Wang, N., \& Liang, H. (2014). Knowledge sharing, intellectual capital and firm performance. Management Decision, 52(2), 230-258.

37. Youndt, M., Subramaniam, M., \& Snell, S. (2004). Intellectual capital profiles: an examination of investment and returns. Journal of Management Studies, 41(2), 335-361.

38. Yu, F., \& Zhang, L. (2008). Does Intellectual capital really create value? IEEE Xplore, November, 18.

39. Zambon, S. (2013). Presentation: Accounting and business economics: A conceptual revisitation In Y. Biondi \& S. Zambon (Eds), Accounting and Business Economics: Insights from National Traditions (pp. 11-22).

40. Zakery, A., Afrazeh, A., \& Dumay, J. (2017). Analysing and improving the strategic alignment of firms' resource dynamics. Journal of Intellectual Capital, 18(1), 217-240. 